\title{
Role of Hydrogen Sulfide, Biologically-Active Compound, During Cell De-Differentiation and Differentiation Processes
}

\author{
Ken Yaegaki* \\ Department of Oral health, Nippon Dental University, Japan
}

Received: March 29, 2018; Published: April 09, 2018

*Corresponding author: Ken Yaegaki, Department of Oral health, Nippon Dental University,1-9-20 Fujimi, Chyodaku, Tokyo, Japan Tel: 81-3-3261-8791; Fax: +81-3-3261-8796; Email: yaegakik@tky.ndu.ac.jp

\begin{abstract}
$\mathrm{H}_{2} \mathrm{~S}$ has been shown to act as a biologically active compound in mammalian cells; $\mathrm{H}_{2} \mathrm{~S}$ may also involve cardio protective or cardiovascular therapeutic effects. The concentrations of NaHS, used instead of $\mathrm{H}_{2} \mathrm{~S}$ at $\mu \mathrm{M}-\mathrm{mM}$, in most of previous studies are higher than the IC $\mathrm{C}_{50}$ or Ki of cytochrome c oxidase ( $\mathrm{COX}$ ) activity by $\mathrm{H}_{2} \mathrm{~S}$. However we found COX is inhibited by only $500 \mathrm{nM} \mathrm{H}_{2} \mathrm{~S}$, reactive oxygen species causing DNA doublestrand breaks are produced, and the mitochondrial membrane is depolarized. Following the above redox reactions, the p53 pathway is activated. Consequently, apoptosis is initiated. If the lowest concentration of $\mathrm{H}_{2} \mathrm{~S}(1 \mathrm{nM})$ is applied for hepatic or pancreatic differentiation from humantooth pulp, the differentiation or proliferation is heavily promoted through WNT signaling and PI3K-AKT signaling pathways. A possibility of regenerative medicine or reversal ageing using $\mathrm{H}_{2} \mathrm{~S}$ at nM level is also suggested. On the other hand previous studies clearly indicated that the accuracy of dose-response studies using $\mathrm{NaHS}$ or $\mathrm{Na}_{2} \mathrm{~S}$ at $\mu \mathrm{M}-\mathrm{mM}$ are questionable, we cannot produce constant concentration of $\mathrm{H}_{2} \mathrm{~S}$ using NaHS. NaHS is easily vaporized, and the dissociation constant of $\mathrm{H}_{2} \mathrm{~S}$ is not equal to that of NaHS. This presents a huge discrepancy affecting investigations of redox biology. The concentration of $\mathrm{H}_{2} \mathrm{~S}$ used for in vitro or in vivo experiments is strongly recommended to be determined by a precise and suitable measure. The review focuses on effects of $\mathrm{H}_{2} \mathrm{~S}$ on apoptosis, typical de-differentiation process, differentiation of the stem cells, and regenerative medicine.
\end{abstract}

Keywords: Hydrogen sulfide; Biologically-active compound; Reactive oxygen species; Apoptosis; Stem cell; Tooth

Abbreviations: $\mathrm{H}_{2} \mathrm{~S}$ : Hydrogen Sulfide; COX: Cytochrome C-Oxidase; MDA: Malon-di-Aldehyde; ROS: Reactive Oxygen Species; CBS: Cystathionine $\beta$-Synthase ; CSE: Cystathionine $\gamma$-Lyase; DCFH-DA: Di-Chloro-Fluorescein Diacetate; HGF: Human Gingival Fibroblasts; Caspase: CysteinylAspartic-Acid-Proteases; NO: Nitric Oxide; CO:Carbon Monoxide; MAPK: Mitogen-Activated Protein Kinase; ERK: Extracellular Signal-Regulated Kinase ; iPS: Induced Pluripotent Stem; ES: Embryonic Stem

\section{Introduction and Background}

Hydrogen sulfide $\left(\mathrm{H}_{2} \mathrm{~S}\right)$ is a poison gas like cyanide; both are strong inhibitors of cytochrome c oxidase (COX; EC 1.9.3.1), which is a crucial enzyme for the respiratory chain in mitochondria [13]. Thus, $\mathrm{H}_{2} \mathrm{~S}$ readily causes cell suffocation leading to death; people attempt suicide using home-produced $\mathrm{H}_{2} \mathrm{~S}$ [4]. $\mathrm{H}_{2} \mathrm{~S}$ causes human death rapidly but the $\mathrm{IC}_{50}$; half maximal $(50 \%)$ inhibitory concentration of COX activity caused by $\mathrm{H}_{2} \mathrm{~S}$ in animals is $0.13 \mu \mathrm{M}$ - $0.30 \mathrm{mM}$ [5-7]. $\mathrm{H}_{2} \mathrm{~S}$ has been also shown to be a gasotransmitter, meaning that $\mathrm{H}_{2} \mathrm{~S}$ is one of the biologically-active compounds required for initiating or supporting biochemical processes in mammalian cells [8]. Gasotransmitters are able to enter into the cell. Cell membranes present no barrier to them [9]. This means that $\mathrm{H}_{2} \mathrm{~S}$ is unlike many of the regular transmitters, which need receptors on the cell membrane to control the signal transduction systems in the cells [8]. The barrier for $\mathrm{H}_{2} \mathrm{~S}$ permeation on the Gibbs energy profile is negligible, and the hydrophobicity of $\mathrm{H}_{2} \mathrm{~S}$ allows it to get into the paraffinic interior of the membrane freely [10]. $\mathrm{H}_{2} \mathrm{~S}$ might control or regulate the process more easily than the regular transmitters do, since $\mathrm{H}_{2} \mathrm{~S}$ permeates cell membranes so easily [10]. Thus, $\mathrm{H}_{2} \mathrm{~S}$ at low concentrations may be involved in many biological activities in mammalian cells.

There is some doubt about the $\mathrm{H}_{2} \mathrm{~S}$ concentrations utilized in studies determining the biological activity of $\mathrm{H}_{2} \mathrm{~S}$, if $\mathrm{H}_{2} \mathrm{~S}$ is provided by exogenous $\mathrm{NaHS}$ or $\mathrm{Na}_{2} \mathrm{~S}$. Most of the studies employed 50-1000 $\mu \mathrm{M}$ of $\mathrm{NaHS}$ in place of $\mathrm{H}_{2} \mathrm{~S}$ for their in vitro studies [11-13]. Some have even employed $\mathrm{Na}_{2} \mathrm{~S}$ instead of $\mathrm{H}_{2} \mathrm{~S}$. The concentrations utilized in these studies are much higher than the $\mathrm{IC}_{50}$ of COX activity by $\mathrm{H}_{2} \mathrm{~S}$. Even animal studies employed higher concentration of $\mathrm{NaHS}$ than 
the $\mathrm{IC}_{50}$ determined by Nicholson et al. [5]. Therefore, cell toxicity of $\mathrm{H}_{2} \mathrm{~S}$ is expected, but the studies have been reported only the positive activities of $\mathrm{H}_{2} \mathrm{~S}$ rather than its cytotoxicity. In measuring malondialdehyde (MDA) content Geng et al. [14] found that NaHS at $100 \mu \mathrm{M}$, which is higher than the $\mathrm{IC}_{50}$ determined by Nicholson et al. [5], almost completely scavenged $0.3 \% \mathrm{H}_{2} \mathrm{O}_{2}$ oxidative stress. Other studies employing NaHS as exogenous $\mathrm{H}_{2} \mathrm{~S}$ have demonstrated that a high concentration of $\mathrm{H}_{2} \mathrm{~S}$ of over $50 \mu \mathrm{M}$, also higher than the $\mathrm{IC}_{50}$, reduces oxidative stress in mammalian cell culture in which reactive oxygen species (ROS) were increased by chemical or other pathological interventions [13,15-19].

On the other hand, no changes were found in cells having a healthy level of ROS (without any intervention) after exposure to high concentrations of NaHS $[16,19]$. Hence, anti-oxidative activity of $50 \mu \mathrm{M} \mathrm{H}_{2} \mathrm{~S}$ is uncertain, the $\mathrm{H}_{2} \mathrm{~S}$ concentration in these reports may not be same as active free $\mathrm{H}_{2} \mathrm{~S}$ concentration. However, antioxidant activity by $\mathrm{H}_{2} \mathrm{~S}$ has been strongly suggested in mammalian tissues. $\mathrm{H}_{2} \mathrm{~S}$ endogenously produced by cysteine reduces ROS, but its concentration is not clear [20]. The usefulness of NaHS in treating cardiac disorders, especially myocardial injury, has been reported [8, 13-17, 19, 21-24], many studies utilized much higher concentration of $\mathrm{H}_{2} \mathrm{~S}$ than the $\mathrm{IC}_{50}$. It has been clearly indicated the potential ability of $\mathrm{H}_{2} \mathrm{~S}$ to control or prevent these conditions, although convinced concentrations of free active $\mathrm{H}_{2} \mathrm{~S}$ has not yet determined. Very high concentration of NaHS at the mM level causes COX inhibition followed by depolarization of mitochondrial membrane [12], leading to the production of large amounts of ROS. Such a concentration of $\mathrm{H}_{2} \mathrm{~S}$ produces oxidative stress through ROS production [11].

This speculation seems to be correct, since $\mathrm{a}_{2} \mathrm{~S}$ concentration higher than that causing anti-oxidative activities increases oxidative stress as reported by others $[8,11,13-15]$. These results were supported by Sun et al. [25]. It has been claimed that most tissues contain $\mathrm{H}_{2} \mathrm{~S}$ at the concentration range of approximately 30- $300 \mu \mathrm{M}$ [15]. However, the cells will not be able to survive in the $\mathrm{mM}$ level of $\mathrm{H}_{2} \mathrm{~S}$. There is a further contradiction here: such a high concentration of $\mathrm{H}_{2} \mathrm{~S}$ at $30-300 \mu \mathrm{M}$ is higher than the $\mathrm{IC}_{50}$ of COX activity by NaHS [5]. Moreover, the Ki, the inhibitor constant, of $\mathrm{H}_{2} \mathrm{~S}$ to COX is only $0.2 \mu \mathrm{M}$ [26]. Furne et al. [26] reported that the real concentration of $\mathrm{H}_{2} \mathrm{~S}$ is only around $15 \mathrm{nM}$ in many tissues, less than one thousandth of the concentration previously claimed, although they spent much time for sampling: this means the production of extra $\mathrm{H}_{2} \mathrm{~S}$ may happen. But they used a precise gas chromatograph with flame photometric or chemiluminescence detector to determine $\mathrm{H}_{2} \mathrm{~S}$ concentration, moreover they produced gas samples for $\mathrm{H}_{2} \mathrm{~S}$ determination rather than tissue-fluid samples containing much non-free $\mathrm{H}_{2} \mathrm{~S}$. So Nicholson et al. [5] and Furne et al. [27] detected only the free form of $\mathrm{H}_{2} \mathrm{~S}$.

Furthermore amount of $\mathrm{H}_{2} \mathrm{~S}$ produced by both $\mathrm{NaHS}$ and $\mathrm{Na}_{2} \mathrm{~S}$ is not constant. $\mathrm{H}_{2} \mathrm{~S}$ production rate depends on $\mathrm{pH}$ [28]. Hence, as Nicholson et al. [5] or Furne et al. did, a gas chromatograph measurement is needed to find the exact concentration of $\mathrm{H}_{2} \mathrm{~S}$. Further discussion regarding the inconsistency of $\mathrm{H}_{2} \mathrm{~S}$ concentration in the tissues may be required. Besides NaHS vaporizes quickly.
Although a reliable sensor with perfect specificity to $\mathrm{H}_{2} \mathrm{~S}$ has not yet developed [29,30], DeLeon et al. [30] found much faster loss of $\mathrm{H}_{2} \mathrm{~S}$ with using a semiconductor sensor, and reported their inability to maintain $\mathrm{H}_{2} \mathrm{~S}$ concentration; also half time, the time required to lose half of the $\mathrm{H}_{2} \mathrm{~S}$, is only $5 \mathrm{~min}$ or less in several experimental conditions: they concluded that the accuracy of dose-response studies are questionable. Part of the basis for the above comments is that a stock solution of NaHS utilized for the $\mathrm{H}_{2} \mathrm{~S}$ studies is never recommended for $\mathrm{H}_{2} \mathrm{~S}$ studies [14]. On the other hand Ariyaratnam et al. [31] have reported that NaHS causes dilatation of human pulmonary arteries and attenuates cardiac dysfunction.

This fact is undisputed; however, the concentrations of $\mathrm{H}_{2} \mathrm{~S}$ actually utilized in those experiments might be different from those reported, because of the inability to determine the true concentration of NaHS present [32]. The method of Gilboa-Garber [33] is frequently employed to determine $\mathrm{H}_{2} \mathrm{~S}$ concentration $[8,19,34,35]$. However the method of Gilboa-Garber [33] quantifies the concentration of inorganic sulfide including $\mathrm{H}_{2} \mathrm{~S}$, the method is not specific to detect $\mathrm{H}_{2} \mathrm{~S}$. A problem lies in that they used NaHS, but they were unable to determine how much of the free form of $\mathrm{H}_{2} \mathrm{~S}$ was present before Nicholson et al. [5], Furne et al. [26] or Yaegaki et al. [29] described how to measure concentrations of $\mathrm{H}_{2} \mathrm{~S}$ in the free form with using a gas chromatography with a flame photometric detector. Yaegaki et al. [29],Calenic et al. [36] and Ii et al. [37] determined the certain concentration of $\mathrm{H}_{2} \mathrm{~S}$ effecting on several tissues with using a $\mathrm{H}_{2} \mathrm{~S}$ gas generator producing a constant concentration instead of NaHS (Figure 1), and the effects of $\mathrm{H}_{2} \mathrm{~S}$ at a $\mathrm{nM}$ level on cell metabolism, the respiratory chain and on apoptosis have been determined.

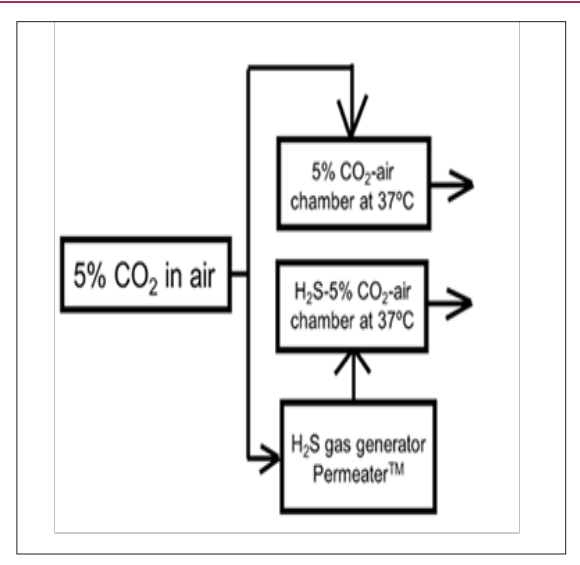

Figure 1: $\mathrm{H}_{2} \mathrm{~S}$ gas-producing system for keeping a constant concentration. NaHS instead of $\mathrm{H}_{2} \mathrm{~S}$ gas is utilized for most other studies, but these do not determine the concentration of the free form of $\mathrm{H}_{2} \mathrm{~S}$ in the medium. As NaHS is easily gasfied, there must be a large loss of $\mathrm{SH}$. Using both our system and a gas chromatograph we can produce less than $100 \mathrm{nM} \mathrm{H}_{2} \mathrm{~S}$ constantly. Instead of the Permeater ${ }^{\mathrm{TM}}$ (GASTEC, Kanagawa, Japan), the Dynacalibrator (VICI Metronic, Houston, USA) can also be uti.

The role of $\mathrm{H}_{2} \mathrm{~S}$ during de-differentiation is relatively well investigated as mentioned above. On the other hand, information on its role during differentiation is very limited. $\mathrm{H}_{2} \mathrm{~S}$ exhibits an important role in the cell viability through controlling redox 
homeostasis by cysteine/glutathione metabolism including cystathionine $\beta$-synthase (CBS) and cystathionine $\gamma$-lyase (CSE) $[13,38,39]$, and by mediation through ion channels [40]. As well, activation of the PI3K-Akt pathway inhibits apoptosis. However, neither the relationship between $\mathrm{H}_{2} \mathrm{~S}$ and stem-cell differentiation nor the role of $\mathrm{H}_{2} \mathrm{~S}$ during differentiation has been clearly determined. The efficacy of the gasotransmitter $\mathrm{H}_{2} \mathrm{~S}$ in regenerative medicine using human-tooth-pulp stem cells has been determined, and a clear positive effect on cell differentiation in regenerated tissues was found $[37,41-43]$. The role of $\mathrm{H}_{2} \mathrm{~S}$ during differentiation is also discussed in this review.

\section{ROS Production, SOD Activity and $\mathrm{H}_{2} \mathrm{~S}$}

It has been previously reported that high concentrations, around $100 \mu \mathrm{M}$ of NaHS, increased ROS scavenging activities in mammalian cells $[8,13-15,20]$. The following hypothesis is still under discussion: $\mathrm{H}_{2} \mathrm{~S}$ evokes a strong antioxidant activity against ROS in mammalian cells, consequently reducing oxidative stress $[8,13-15,20]$. It has also been suggested that $d$-cysteine may protect tissues, especially heart, from ROS and even from ischemia, due to $\mathrm{H}_{2} \mathrm{~S}$ produced from d-cysteine by CBS, CSE or 3-metacaptopyruvate sulfurtransferase [8,13-20]. Hence Yang et al. [13] have been implied that $\mathrm{H}_{2} \mathrm{~S}$ decreases the amount of pathologically-elevated ROS by inhibiting the ROS-activated NF-kB pathway or by increasing the activity of superoxide dismutase (SOD) [15]. Hence, pathologically elevated ROS might be decreased by administrating NaHS as an exogenous form of $\mathrm{H}_{2} \mathrm{~S}[15,19]$, although the real concentration of active $\mathrm{H}_{2} \mathrm{~S}$ is not clear. On the other hand, NaHS does not increase ROS in mammalian cells that are in a normal or healthy condition [19]. Based on those studies there is another hypothesis: it is claimed that $\mathrm{H}_{2} \mathrm{~S}$ administration might be a novel cardiovascular therapeutic procedure $[8,16]$.

The assertion that such a high concentration (hundred $\mu \mathrm{M}$ level) NaHS can protect the cells from ROS rather than causing damage to the cells may need to be taken under careful reconsideration and further research for the following reasons: Ago et al. [44] reported that a $100 \mu \mathrm{M}$ sulfur introduced by $\mathrm{H}_{2} \mathrm{~S}$ inhalation causes human death. Cysteine, around $100 \mu \mathrm{M}$, is known to cause cell death, and cysteine significantly elevates in patients who suffer early stroke deterioration, cysteine converts to $\mathrm{H}_{2} \mathrm{~S}$, indicating that $\mathrm{H}_{2} \mathrm{~S}$ may be acting as a mediator of ischemic brain damage [45]. Inhibition of $\mathrm{H}_{2} \mathrm{~S}$ formation was also suggested as a novel approach in acute stroke therapy [45]. Mann et al. [46] implied a cause of sudden infant death syndrome (SIDS): the $\mathrm{H}_{2} \mathrm{~S}$ detoxifying system at the colon surface may not have matured by the age of 3 months, so $\mathrm{H}_{2} \mathrm{~S}$ could possibly be absorbed, resulting in SIDS. It is clear that $\mathrm{H}_{2} \mathrm{~S}$ inhibits COX, leading to cellular asphyxia $[1,47,48]$. In the mitochondrial respiratory chain COX is the terminal enzyme (complex IV), SIDS might increases ROS production dramatically in a burst $[48,59,50]$.

There is another outstanding question concerning the protective or curative effect of NaHS in situations like heart or myocardial conditions, i.e. both pathways of AMPK and AKT are activated by $\mathrm{H}_{2} \mathrm{~S}$ for cardio protection, but AKT negatively controls
AMPK [19,49,52]. These contradictions might happen because they did not make accurate and exact measurements of active $\mathrm{H}_{2} \mathrm{~S}$ concentration [32]. To confirm the hypothesis that $\mathrm{H}_{2} \mathrm{~S}$ has protective/treatment effects on heart conditions, further studies are required to determine the safe and effective concentration of $\mathrm{H}_{2} \mathrm{~S}$ that will prevent or treat these conditions. On the other hand, application of $500 \mathrm{nM} \mathrm{H}_{2} \mathrm{~S}$, which is less than that found in human gingival crevicular fluid in periodontal conditions producing much amount of volatile sulfur compounds as the colon does [53], and which is less than one hundredth of the exogenous NaSH utilized in previous researches, increased the amount of ROS, including all mitochondrial ROS present, and inhibited SOD activity [54], which results are totally different from those found by other researchers $[11,13-15,55]$. However, all of them used $\mu$ M level or more of NaHS. Sun et al. [15] and Eghbal et al. [11] and Yang et al. [13] utilized 2',7'-dichlorofluorescein diacetate (DCFH-DA) to determine ROS value.

DCFH-DA detects mainly hydrogen peroxide or hydroxyl and peroxyl radical in cytosol even though the manufacturer's instructions claim that the product is for detecting ROS [56]. Geng et al. [14] detected malondialdehyde which is byproduct from ROS, they did not directly measure ROS. Shibuya et al. [55] did not determined amount of $\mathrm{O}_{2}^{-}$. But Yaegaki et al. [54] detected $\mathrm{O}_{2}^{-}$in mitochondria. Furthermore $\mathrm{H}_{2} \mathrm{~S}$ at $500 \mathrm{nM}$ does not increase any activity of ROS scavengers [36,54,57-61]. On the other hand 500 nM $\mathrm{H}_{2} \mathrm{~S}$ inhibited SOD strongly and increased ROS greatly [54]. If such a low concentration (500 nM) of $\mathrm{H}_{2} \mathrm{~S}$ inhibits SOD and produces ROS, much higher $\mathrm{H}_{2} \mathrm{~S}$ concentrations ( $\mu \mathrm{M}$ levels) may not be able to scavenge ROS. The effects of exogenous NaHS on ROS production and the process are not clear. CuZn-SOD (E.C.1.15.1.1; Sigma-Aldrich, Oakville, ON, Canada), Mn-SOD (E.C.1.15.1.1; Wako Pure Chemical, Tokyo, Japan) and also SOD in human gingival fibroblasts (HGF) homogenate were exposed to $500 \mathrm{nM} \mathrm{H}_{2} \mathrm{~S}$ [54]. The percentage inhibition of CuZn-SOD and Mn-SOD was found to be around $70-80 \%$ for $1 \mathrm{~h}$ incubation and increased in proportion to incubation time.

The inhibition of HGF-SOD was 80\% [54]. They found that such a low concentration of $\mathrm{H}_{2} \mathrm{~S}$ inhibits SOD activity rather than protecting the cells from ROS. All cells in their studies are human cells. It is very unlikely that a concentration as high as $50-100 \mu \mathrm{M}$ of NaHS would reduce oxidative stress. There is a possible ironic explanation of why 50-100 $\mu \mathrm{M}$ of NaHS reduces ROS: since a high concentration of NaHS reduces cell vitality, biological products including ROS might also decrease. Part of the toxicity of $\mathrm{H}_{2} \mathrm{~S}$ to mammalian cells is ROS production, which may cause DNA damage $[11,12,62]$. Further studies would be required to confirm if $\mathrm{H}_{2} \mathrm{~S}$ increase or decreases oxidative stress.

There is a possible ironic explanation of why $50-100 \mu \mathrm{M}$ of NaHS reduces ROS: since a high concentration of NaHS reduces cell vitality, biological products including ROS might also decrease. Part of the toxicity of $\mathrm{H}_{2} \mathrm{~S}$ to mammalian cells is ROS production, which may cause DNA damage [11,12,62]. Further studies would be required to confirm if $\mathrm{H}_{2} \mathrm{~S}$ increase or decreases oxidative stress. 


\section{$\mathrm{H}_{2} \mathrm{~S}$ Damages DNA}

Gasotransmitters that regulate physiological responses are produced endogenously, but extraneously-produced $\mathrm{H}_{2} \mathrm{~S}$ also affects the human tissues. Human oral tissues are much easily and simply biopsied compared with other human tissues, and can be a source of human-cell primary cultures. Moreover it is possible to obtain a large number of volunteer, each volunteer gives one independent result. The effects of extrinsic $\mathrm{H}_{2} \mathrm{~S}$ on several fresh tissues or cells from humans have been easily determined [36,54,57-61]. Their hypothesis is that $\mathrm{H}_{2} \mathrm{~S}$ is the cause of oral conditions such as periodontitis and ageing of mucosa or alveolar bone, since they used the concentration of $\mathrm{H}_{2} \mathrm{~S}$ existing in human gingival crevices, and as the tissues are exposed to $\mathrm{H}_{2} \mathrm{~S}$ for one or more day. $\mathrm{Ng}$ and Tonzetich [63] reported that the permeability of human mucosa is dramatically increased after exposing the epithelial surface to $\mathrm{H}_{2} \mathrm{~S}$; around $100 \%$ of the $\mathrm{H}_{2} \mathrm{~S}$ penetrates and gets through the epithelia and into the underlying tissues. The effects of penetrating $\mathrm{H}_{2} \mathrm{~S}$ on biological transduction may escalate to pathological reactions, resulting in damage to the integrity of the tissue. The effects of penetrating $\mathrm{H}_{2} \mathrm{~S}$ on biological transduction may escalate to pathological reactions, resulting in damage to the integrity of the tissue Yaegaki et al. [54] concluded that $\mathrm{H}_{2} \mathrm{~S}$ causes DNA damage by increased ROS. DNA damage caused by ROS is at the root of apoptosis caused by intrinsic pathways to protect the individual from expected conditions, e.g. malignant tumors [64]. Many papers have reported or suggested that high concentrations of exogenous $\mathrm{H}_{2} \mathrm{~S}$ reduce oxidative stress; however, the effect of increased $\mathrm{H}_{2} \mathrm{~S}$ on DNA has not yet been made clear [8,13-15,20]. Baskar et al. [64] found that $50 \mu \mathrm{M}$ NaHS caused micronuclei formation, an indicator of DNA damage using human lung fibroblasts. Yaegaki et al. [54] and others [36,57-61] found or suggested DNA damage caused by only $500 \mathrm{nM} \mathrm{H}_{2} \mathrm{~S}$ in several human tissues or cells. $\mathrm{H}_{2} \mathrm{~S}$ concentration was determined by a gas chromatography with flame photometric detector as described above. $\mathrm{H}_{2} \mathrm{~S}$ is expected to cause DNA damage followed by activating the p53-pathway for apoptosis [64]. DNA damage was evaluated by single-cell electrophoresis (Comet Assay ${ }^{\mathrm{TM}}$; Trevigen). Baskar et al. [64] utilized DNA ladder agarose electrophoresis for confirming DNA damage. However the purpose of DNA ladder is for detecting apoptosis. But Comet Assay ${ }^{\mathrm{TM}}$; was designed to detect DNA damage.

Yaegaki et al. [54] concluded that $\mathrm{H}_{2} \mathrm{~S}$ causes DNA damage by increased ROS. DNA damage caused by ROS is at the root of apoptosis caused by intrinsic pathways to protect the individual from expected conditions, e.g. malignant tumors [64]. Many papers have reported or suggested that high concentrations of exogenous $\mathrm{H}_{2} \mathrm{~S}$ reduce oxidative stress; however, the effect of increased $\mathrm{H}_{2} \mathrm{~S}$ on DNA has not yet been made clear [8,13-15,20]. Baskar et al. [64] found that $50 \mu \mathrm{M}$ NaHS caused micronuclei formation, an indicator of DNA damage using human lung fibroblasts. Yaegaki et al. [54] and others [36,57-61] found or suggested DNA damage caused by only $500 \mathrm{nM} \mathrm{H}_{2} \mathrm{~S}$ in several human tissues or cells. $\mathrm{H}_{2} \mathrm{~S}$ concentration was determined by a gas chromatography with flame photometric detector as described above. $\mathrm{H}_{2} \mathrm{~S}$ is expected to cause DNA damage followed by activating the p53-pathway for apoptosis [64]. DNA damage was evaluated by single-cell electrophoresis (Comet Assay ${ }^{\mathrm{TM}}$; Trevigen). Baskar et al. [64] utilized DNA ladder agarose electrophoresis for confirming DNA damage. However the purpose of DNA ladder is for detecting apoptosis. But Comet Assay ${ }^{\mathrm{TM}}$; was designed to detect DNA damage. Baskar et al. [64] indicated that $\mathrm{H}_{2} \mathrm{~S}$ evokes the caspase (cysteinyl-aspartic-acid-proteases) pathway in human lung fibroblasts, because $\mathrm{H}_{2} \mathrm{~S}$ may cause DNA double strand breaks. In the apoptotic process involving mitochondria, caspase-3 is an executing enzyme [66]. In proportion to oxidative stress and DNA damage, caspase- 3 activity is increased $[54,60]$. They assessed the mitochondrial membrane potential treated with $500 \mathrm{nM} \mathrm{H}_{2} \mathrm{~S}$. Under $\mathrm{H}_{2} \mathrm{~S}$ exposure for 1-3 days around $25 \%$ of the cells were depolarized, while the control group showed only 5 - $6 \%$ depolarized cells. Releasing cytochrome c from mitochondria into cytosol is an important process in the activation of the caspase pathway. They detected increased cytochrome c release from mitochondria, and determined that cytochrome c activates caspase-9. The released cytochrome c increased around 10 times compared with controls [60]. They also measured the activities of caspase- 9 and -8, finding that only caspase- 9 was increased by $\mathrm{H}_{2} \mathrm{~S}[60]$.

Also, in the cells originated from several human tissues, only caspase-9 was activated [36,57,61]. However, Aoyama et al. [67] reported that $\mathrm{H}_{2} \mathrm{~S}$ increased both caspase- 8 and -9 in osteoblasts. Hence they investigated the effects of $\mathrm{H}_{2} \mathrm{~S}$ on the receptors and functions of the extrinsic caspase pathway: human Fas ligand, TNFalpha, IL1-alpha, IL-b, IL-2, IL-4, IL-10, interferon-c, granulocytecolony-stimulating factor and granulocytemacrophage-colonystimulating factor. None of these receptors or cytokines was activated by $\mathrm{H}_{2} \mathrm{~S}$, suggesting that novel factor, not yet been determined, may stimulate caspase-8 [67]. From the above findings, the apoptotic pathway initiated by $500 \mathrm{nM} \mathrm{H}_{2} \mathrm{~S}$ is summarized as shown in Figure 2.

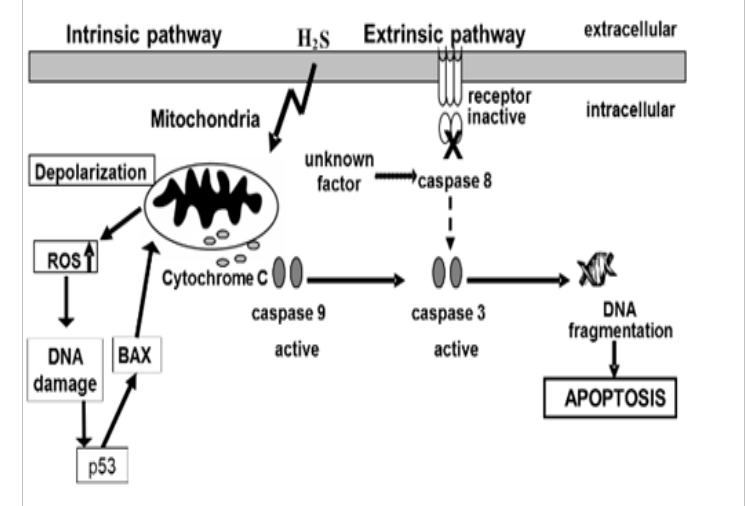

Figure 2: Simple apoptotic pathways caused by $\mathrm{H}_{2} \mathrm{~S}$. Broken line indicates activity in osteoblasts [36].

\section{$\mathrm{H}_{2} \mathrm{~S}$ Inhibits Apoptosis in Human Tissues?}

$\mathrm{H}_{2} \mathrm{~S}$ is a gasotransmitter like nitric oxide (NO) or carbon monoxide (CO). NO and CO cause or inhibit apoptosis, depending on cell types [68]. There are arguments on both sides as to whether $\mathrm{H}_{2} \mathrm{~S}$ inhibits or causes apoptosis $[17,25,64,68]$. Wu et al. [17] 
reported the anti-apoptotic effect of $100 \mu \mathrm{M} \mathrm{H}_{2} \mathrm{~S}$ in cardiomyocytes by antioxidative activity of $\mathrm{H}_{2} \mathrm{~S}$ through the SIRT1 pathway. Zhen et al. [17] found that NaHS at $500 \mu \mathrm{M}$ induces cell proliferative or anti-apoptotic effects by activating the NF- $\kappa$ B pathway. But 100$500 \mu \mathrm{M}$ of NaHS was utilized as the exogenous $\mathrm{H}_{2} \mathrm{~S}$ source in these studies is much higher than $\mathrm{IC}_{50}$ or Ki. On the other hand Yang et al. [68] investigated whether $\mathrm{H}_{2} \mathrm{~S}$ caused apoptosis in human aorta smooth-muscle cells. Exogenous $\mathrm{H}_{2} \mathrm{~S}$ originated from NaHS did not induce significant cell necrosis and LDH release, but very high concentration $\mathrm{NaSH}(500 \mu \mathrm{M})$ increased the number of condensed apoptotic nuclei, accompanied by the typical morphological changes of apoptosis.

Furthermore, NaHS also increased the number of TUNELpositive cells, and DNA fragmentation was confirmed by DNA ladder agarose gel electrophoresis. NaHS induced apoptosis in human aorta smooth-muscle cells. They found around 10\% incidence of apoptosis after incubating the cells with $200 \mu \mathrm{M}$ NaHS for $12 \mathrm{~h}$. Also similar apoptosis happened in neurons [69]. Takeuchi et al. [70] carried out cell-cycle analysis after exposure to $\mathrm{H}_{2} \mathrm{~S}$ expected to be lower than $1 \mu \mathrm{M}$, using the same $\mathrm{H}_{2} \mathrm{~S}$-exposure system as Yaegaki et al. [54] used (Figure 1). The proportion of cells in G (1) phase was significantly increased and the cells in $S$ phase significantly decreased. Moreover Rb phosphorylation was reduced and p21 (Cip1) expression was increased after exposure to $\mathrm{H}_{2} \mathrm{~S}$. They concluded that $\mathrm{H}_{2} \mathrm{~S}$ inhibits cell proliferation and induces cell-cycle arrest through p21 (Cip1) in the HeLa cell line. It was also suggested that $\mathrm{H}_{2} \mathrm{~S}$ might cause apoptosis in human-oral keratinocytes.

Yaegaki et al. [54], Calenic et al. [36,57,58,61] found that a similar apoptotic process determined in the Hela cells also happened in human-skin keratinocyte stem cells and human primary oral keratinocyte stem cells. Human oral-keratinocyte stem cells were separated from human biopsies using a protocol established by Calenic et al. [58]. p53 expression was induced by $500 \mathrm{nM} \mathrm{H}_{2} \mathrm{~S}$ in the cells [57]. As previously demonstrated, the number of apoptotic cells among these cells was significantly increased after exposure to $500 \mathrm{nM} \mathrm{H}_{2} \mathrm{~S}[57,58,59]$. In the apoptotic process DNA fragmentation indicating apoptosis was increased, ROS production was also increased, mitochondrial membrane potential was collapsed, and there was a significant amount of cytochrome c released into the cytosol. Caspase- 9 and -3 activities were also significantly increased by $\mathrm{H}_{2} \mathrm{~S}$ exposure, but caspase- 8 activity was not increased except osteoblasts MC3T3-E1 from mouse [67].

Calenic et al. $[57,58]$ measured p53 and the related gene BAX to determine if the p53 pathway is stimulated by DNA damage caused by $500 \mathrm{nM} \mathrm{H}_{2} \mathrm{~S}$. A member of the Bcl-2 protein family, Bax is the primary response gene to p53, and starts after p53-mediated apoptosis [71]. Total p53, phosphorylated p53 Serine 46 and Bax were significantly increased after $\mathrm{H}_{2} \mathrm{~S}$ incubation. In particular, both total and p53 phosphorylated p53 at serine 46 were dramatically increased after exposure to $\mathrm{H}_{2} \mathrm{~S}$. These data demonstrated that the p53 pathway plays the most important role in apoptosis caused by $\mathrm{H}_{2} \mathrm{~S}$. A simple apoptotic pathway caused by $500 \mathrm{nM} \mathrm{H}_{2} \mathrm{~S}$ is summarized in Fig. 2. The expression of all genes appearing in the p53 pathway activated by $500 \mathrm{nM} \mathrm{H}_{2} \mathrm{~S}$ was determined; more details of the p53-pathway-related cell cycle and DNA repair are found (Figure 3) [61]. From these reports it was suggested that the gasotransmitter $\mathrm{H}_{2} \mathrm{~S}$, of which the concentration might be much less than previously expected, may cause apoptosis.

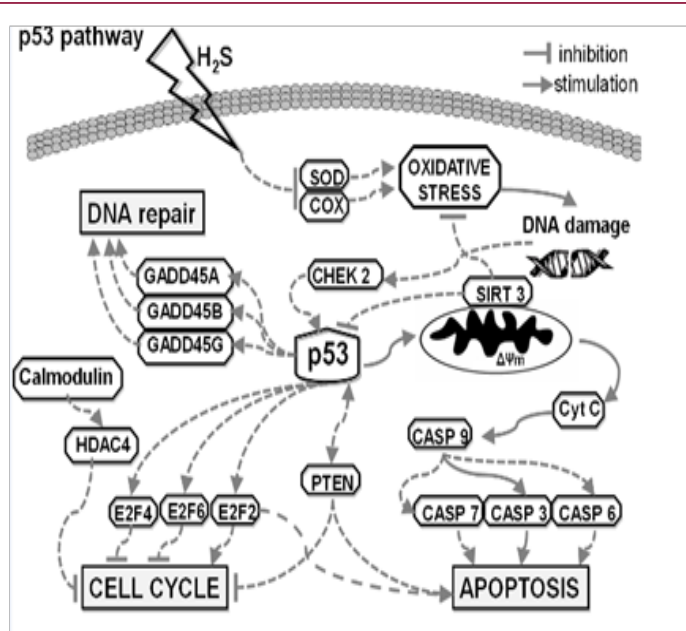

Figure 3: Cell cycle, DNA repair and apoptotic pathways initiated by $500 \mathrm{nM} \mathrm{H}_{2} \mathrm{~S}$ [61].

\section{$\mathrm{H}_{2} \mathrm{~S}$ Differentiates Osteoclasts Rather Than Demonstrat- ing its Toxicity}

Zhou et al. [49] found that $100 \mu \mathrm{M}$ NaSH inhibited mitogenactivated protein kinase (MAPK) and c-Jun N-terminal kinase p38 pathways, and then activated PI3K/Akt signaling in cardiomyocytes, when $\mathrm{H}_{2} \mathrm{~S}$ reduced high-glucose-induced apoptosis both in vitro and in vivo. On the other hand Imai et al. [72] found that $500 \mathrm{nM}$ $\mathrm{H}_{2} \mathrm{~S}$ inhibits the proliferation of osteoblasts through the MAPK pathway as shown in Fig. 4. This contradiction might depend on the differences in the concentrations or the tissues. It was also found that $500 \mathrm{nM} \mathrm{H}_{2} \mathrm{~S}$ causes apoptosis in osteoblasts, as described above [67]. Ii et al. [37] determined the effects of $\mathrm{H}_{2} \mathrm{~S}$ on osteoclast differentiation. When the murine macrophage cell line RAW264 was exposed to only $1 \mathrm{nM} \mathrm{H}_{2} \mathrm{~S}$ instead of $500 \mathrm{nM}$, osteoclasts were differentiated from the cell without nuclear factor-kappa B ligand (RANKL) [37].

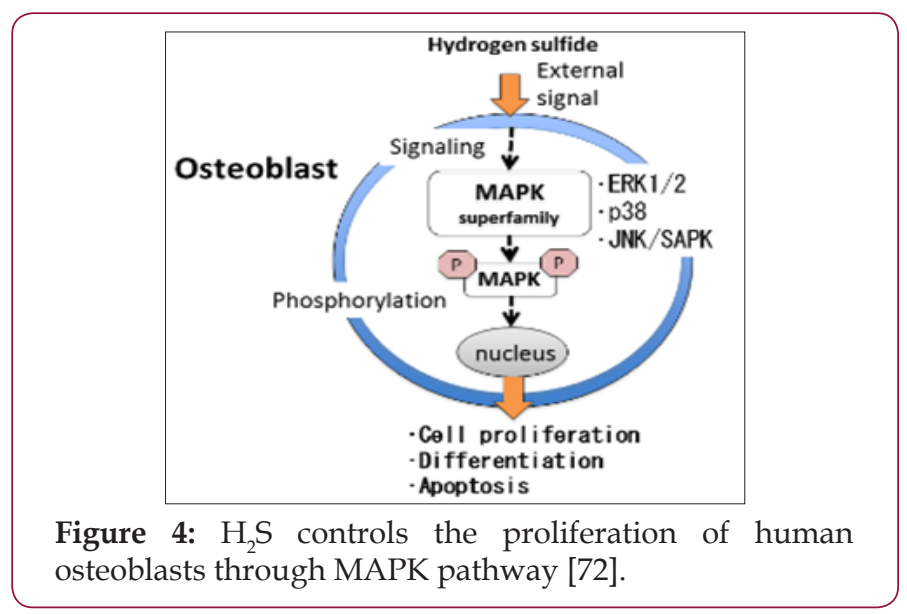

A recent review has demonstrated that the strength of osteoclast 
differentiation by a receptor-activator of RANKL is dependent on the redox state of the precursor cells, macrophages, that is controlled by $\mathrm{H}_{2} \mathrm{~S}$ [73]. Ii et al. [37] determined the effects of MAPK inhibitors on RAW264 cell differentiation by $\mathrm{H}_{2} \mathrm{~S}$, extracellular signal-regulated kinase (ERK) inhibitor and p38 inhibitor suppressed osteoclast differentiation by $\mathrm{H}_{2} \mathrm{~S}$. They concluded that $\mathrm{H}_{2} \mathrm{~S}$ at $1 \mathrm{nM}$ in the medium differentiated osteoclasts from RAW264 through MAPK [37]. Lee et al. [74] determined the effects of NaHS on nicotineand LPS-induced osteoblastic and osteoclastic differentiation, and found that the differentiations were inhibited by MKP-1 enzyme inhibitor (vanadate) and expression inhibitor (triptolide). These findings strongly suggest that $\mathrm{H}_{2} \mathrm{~S}$ has effects on the differentiation of stem cells, especially adult stem cells.

\section{$\mathrm{H}_{2} \mathrm{~S}$ and Ion Channel}

$\mathrm{H}_{2} \mathrm{~S}$ influences a number of biological compounds, one of them being T-type $\mathrm{Ca}^{2+}$ channels. The T-type $\mathrm{Ca}^{2+}$ channel is the lowvoltage activated channel activated by depolarization of the plasma membrane. The T-type $\mathrm{Ca}^{2+}$ channel involves three isoforms: $\mathrm{C}_{\text {av }} 3.1$, $\mathrm{Ca}_{\mathrm{v}} 3.2$ and $\mathrm{Ca}_{\mathrm{v}}$ 3.3. $\mathrm{H}_{2} \mathrm{~S}$ appears to affect $\mathrm{Ca}_{\mathrm{v}} 3.2$ channel activity especially using human embryonic kidney cells [75]. Ca 3.2 channel is blocked by zinc, since it binds to a histidine residue on the channel protein [76]. $\mathrm{H}_{2} \mathrm{~S}$ activates $\mathrm{Ca}_{\mathrm{v}} 3.2$ channel by interacting with zinc binding to the histidine residue at the channel [77]. $\mathrm{H}_{2} \mathrm{~S}$ also activates the KATP channel through cysteine sulfhydration, resulting in relaxation of vascular muscle [40]. Neurite outgrowth and altered electrophysiological changes, i.e. an increase of voltagegated $\mathrm{Na}+$ and/or $\mathrm{Ca}^{2+}$ channels, in neuronal progenitor or stem cells indicate neuronal differentiation of the progenitor or stem cells [78]. Very high concentrations of $\mathrm{H}_{2} \mathrm{~S}$ (mM level of NaHS), which would not exist in mammalian cells, induced neuronal differentiation from the progenitor or stem cells, since neurite outgrowth and increase of the high voltage-activated current in the cells through the channels were observed [79]. Consequently, activating $\mathrm{Ca}_{v} 3.2$ T-type $\mathrm{Ca}^{2+}$ channels with $\mathrm{H}_{2} \mathrm{~S}$ induces neuronal differentiation of the progenitor cells.

\section{$\mathrm{H}_{2} \mathrm{~S}$ and Neuronal Differentiation}

The relationship between $\mathrm{H}_{2} \mathrm{~S}$ and neuronal differentiation was also brought into focus [40] but this has not yet been done for other tissues. It has been suggested that endogenous $\mathrm{H}_{2} \mathrm{~S}$ protects neurons from oxidative stress [38]. Oxidative stress is a plausible reason for neuronal damage or conditions in the brain, including stroke, epilepsy, and Alzheimer's disease [80,81]. Oxytosis, oxidative stress caused by glutamate, is a typical condition for neural tissues. $\mathrm{H}_{2} \mathrm{~S}$ protects primary neuron cultures of rat cortex from cell death caused by oxytosis [38]. Glutathione is produced by enhancing the activity of $\gamma$ - glutamylcysteine synthetase and up-regulating cysteine transport. Cysteine is the substrate of glutathione synthesis. Glutathione normally decreases oxidative stress caused by $\mathrm{H}_{z} \mathrm{O}_{2}$. Glutamate inhibits transport of cysteine into the cell, thus oxytosis is caused by glutamate. They found that $\mathrm{NaSH}$ at $100 \mu \mathrm{M}$ increases the glutathione concentration [38]. In this way $\mathrm{H}_{2} \mathrm{~S}$ protects neurons from oxytosis. Moreover, Jiang et al. [82] reported that $\mathrm{H}_{2} \mathrm{~S}$ protected neuronal cells from formaldehyde- induced oxidative stress through the BDNF-TrkB pathway, reducing oxidative stress and controlling apoptosis by increasing Bax expression and decreasing Bcl-2 expression.

Because of the anti-oxidative activities of $\mathrm{H}_{2} \mathrm{~S}$, a positive effect on differentiation from neural stem cells can be expected. Liu et al. [81] examined the effects of $\mathrm{H}_{2} \mathrm{~S}$ on mouse neural stem cells, and the underlying molecular mechanisms. NaHS at $0.5-5 \mu \mathrm{M}$ promoted proliferation and neuronal differentiation of neural stem cells, NaHS-induced proliferation was caused by activating ERK. Neuronal proliferation was also activated through expression of the basic helix-loop-helix transcription Factors: neurogenin 1, NeuroD2 and mammalian achaete-scute homologue 1 [81, 83]. Zhao et al. [84] reported that NaHS increased the proliferation of human iPS-cell-derived mesenchymal stromal cells via the PI3KAkt pathway. Wang et al. [21] also determined the effects and mechanism of endogenous $\mathrm{H}_{2} \mathrm{~S}$ on the in vitro proliferation and differentiation of neural stem cells. They found that L-cysteine stimulated proliferation and increased the differentiation potential of neural stem cells through cystathionine $\beta$ synthase $/ \mathrm{H}_{2} \mathrm{~S}$ and ERK pathways. In an in vivo study, NaHS administration increased the number of proliferating cells in the hippocampus of mouse after hypoxia. Moreover the administration of NaHS allowed recovery from cognitive impairment in mice subjected to hypoxia. Hence, a $\mathrm{H}_{2} \mathrm{~S}$ donor could be used for neuronal treatment, and to improve endogenous neurogenesis [81].

\section{Effects of $\mathrm{H}_{2} \mathrm{~S}$ on Regenerative Medicine: Hepatic and Pancreatic Differentiation from Human-Tooth Pulp}

It has been shown that transplantation of hepatocyte-like cells differentiated from human tooth pulp perfectively treated liver cirrhosis produced in rats [85]. It was never happened before, although adult stem cells are being used to treat diseases. On the other hand, embryonic stem (ES) cells and induced pluripotent stem (iPS) cells demonstrate the largest capacity for multilineage differentiation. However, the former involves an ineluctable ethical problem and the great possibility of producing a malignant tumor. The latter may have the same problems, and genetic modification might cause further trouble in the future: its possibility of producing malignancy may be higher than in adult stem cells [86]. In fact. Institute of Physical and Chemical Research (Japan) send-off their second retina transplantation using human iPS cells because of DNA sequence modification [87]. Regenerative medicine using stromal mesenchymal stem cells is much safer than using ES or iPS cells. Human-tooth pulp cells showed expression of CD117, nanog, nestin, CD44, alkaline phosphatase, Oct3/4, CK18, CK19, osteonectin and P63. Nanog and Oct3/4 are markers of ES or iPS cells [88]. Approximately $70 \%$ of the primary culture showed stem-cell markers, and the $\mathrm{CD} 117^{+}$fraction, which forms $50 \%$ of the primary culture, is now utilized for hepatic or pancreatic differentiation.

The protocol for hepatic differentiation directly from deciduous- and wisdom-tooth pulp was established [88], and then a new protocol using non-serum medium for hepatic differentiation 
was developed [89]. It was also suggested that $\mathrm{H}_{2} \mathrm{~S}$ may directly affect hepatic and pancreatic differentiation [37,41-43]. On the other hand the relationship between $\mathrm{H}_{2} \mathrm{~S}$ and human-tooth-pulp stem cells has also been well reported. The CD117 ${ }^{+}$fraction of deciduous-tooth-pulp stem cells were incubated with $1 \mathrm{nM} \mathrm{H} 2 \mathrm{~S}$ produced using a Permeater ${ }^{\mathrm{TM}}$ (GASTEC, Kanagawa, Japan), as shown in Figure 1. All the cells differentiated into hepatic cells [41]. Glycogen storage happens in hepatocyte-like-cells; it is the distinguishing function of hepatocytes. Increased accumulations

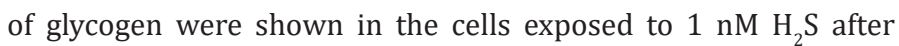
several days (Figure 5). Urea concentrations in the medium of the cells increased after $\mathrm{H}_{2} \mathrm{~S}$ exposure [41]. It was concluded that $\mathrm{H}_{2} \mathrm{~S}$ exposure produces more matured hepatocyte-like cells which have much less possibly of producing malignancy compared with initialized stem cells or direct transplantation of stromal stem cells without in vitro differentiation.

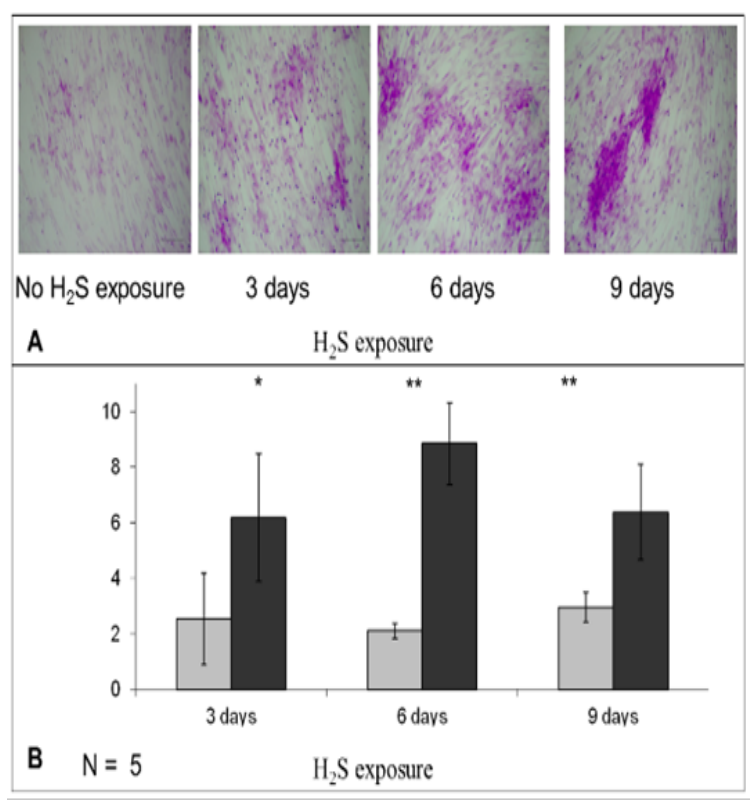

Figure 5: Glycogen storage in hepatocyte-like cells. (A) Cytoplasmic glycogen storage after the differentiation period (PAS staining, $\times 200)$. (B). The area was evaluated with Image J, and the proportion of positive cells in samples exposed to $\mathrm{H}_{2} \mathrm{~S}$ was compared with that in non-exposed samples [41]. ${ }^{*} \mathrm{p}<0.05,{ }^{* *} \mathrm{p}<0.001$.

They have also compared the effects of $\mathrm{H}_{2} \mathrm{~S}$ exposure on human deciduous-tooth-pulp stem cells with those on human-bone marrow stem cells $[42,43]$. They confirmed that the expression level of stem-cell-related transcription factors (112 factors) was almost the same between $\mathrm{CD} 117^{+}$tooth-pulp stem cells and bonemarrow stem cells in six groups: ectodermal-lineage markers, mesodermal-lineage markers, endodermal-lineage markers, stemcell/embryonic-development markers related to late embryonic development, axis/symmetry/segmentation-markers associated with early embryonic development, and other pluripotency markers supporting pluripotency and regenerative abilities. DLX2 and MSX2 showed significant increases in tooth-pulp stem cells compared with bone-marrow stem cells; significant decreases were found in EGR3 and NANOG. Expression of OLIG2, GATA6, EGR3 and ESR1 was found only in bone-marrow stem cells [43].

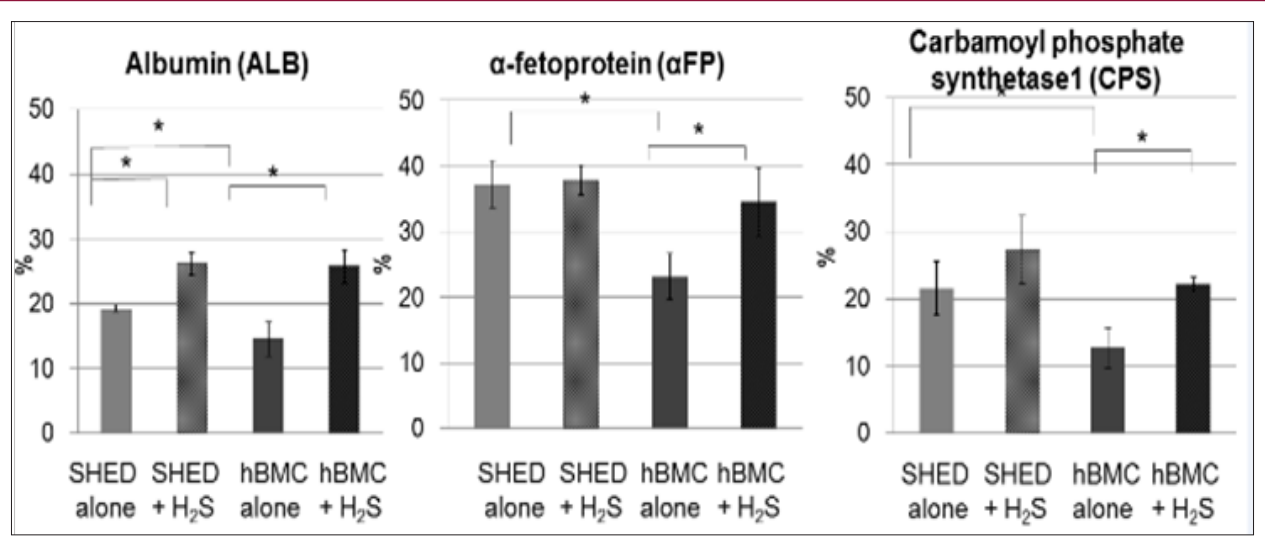

Figure 6: Flow cytometric analysis. Almost $100 \%$ of cells were positive to ALB, a- FP and CPS by microscopic examination; however, flow cytometric data showed smaller numbers, possibly because of a higher detection threshold. It was expected that more matured cells would be detected by a flow cytometer. Significant differences amongst CD117 $7^{+}$tooth-pulp stem cells, bone-marrow stem cells and $\mathrm{H}_{2} \mathrm{~S}$ treatment were found [42]. ${ }^{*} \mathrm{p}<0.01$. 
Almost $100 \%$ of hepatic differentiated cells were positive for

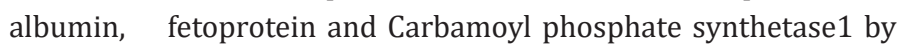
microscopic examination, hence quantitative flow-cytometric data was obtained and showed smaller numbers than those obtained by microscopic examination, perhaps because of the higher detection threshold (Figure 6). It had been anticipated that more matured cells would be detected by a flow cytometer. Human-tooth showed more positive cells for albumin, 凶xfetoprotein and carbamoyl phosphate synthetase 1 than human-bone-marrow stem cells. $\mathrm{H}_{2} \mathrm{~S}$ increased the number of positive cells in both types (Figure 6) [42].

It was concluded that $\mathrm{H}_{2} \mathrm{~S}$ promotes hepatic differentiation from human-tooth pulp stem cells, and thus more matured hepatocytelike cells are obtained. Hepatocyte-like cells differentiated under exposure to $\mathrm{H}_{2} \mathrm{~S}$ might result in great clinical success when these cells are utilized to regenerate the liver in future. As described above, even implantation of non- $\mathrm{H}_{2} \mathrm{~S}$-treated cells was able to treat liver cirrhosis produced in rats (Figures 7\&8) [85], but no preclinical study using hepatocyte-like cells has succeeded before. $\mathrm{H}_{2} \mathrm{~S}$-treated cells might be able to transform the regenerated liver into mature. Ishkitiev et al. [90] differentiated pancreas-like cells from the $\mathrm{CD} 117^{+}$fraction of human-tooth-pulp, describing
Concentration of urea in the culture medium was determined after hepatic differentiation. Urea concentration for $\mathrm{H}_{2} \mathrm{~S}$-treated cells significantly increased in the media of both cell types, compared with non- $\mathrm{H}_{2} \mathrm{~S}$-treated control cells. $\mathrm{H}_{2} \mathrm{~S}$ increased urea concentrations in a time-dependent manner. After 9 days of $\mathrm{H}_{2} \mathrm{~S}$ exposure, the urea concentration had increased almost one-and-a-half fold compared to non- $\mathrm{H}_{2} \mathrm{~S}$-treated cells. Urea production in non- $\mathrm{H}_{2} \mathrm{~S}$-treated tooth pulp was also found to be significantly higher than non- $\mathrm{H}_{2} \mathrm{~S}$-treated bone-marrow cells.

the pathways of pancreatic transcription factors and hormones in differentiating the cells into pancreatic cells (Fig. 9); they also determined the effects of $\mathrm{H}_{2} \mathrm{~S}$ on pancreatic differentiation from human-tooth, and how $\mathrm{H}_{2} \mathrm{~S}$ affects it through WNT and PI3KAKT signaling pathways [43]. Flow-cytometric analysis for cells expressing insulin and glucagon was carried out. $\mathrm{H}_{2} \mathrm{~S}$ increased the number of cells expressing insulin compared to non- $\mathrm{H}_{2} \mathrm{~S}$-treated cells, but decreased the number of glucagon-positive cells. Thus the pancreatic cells produced by $\mathrm{H}_{2} \mathrm{~S}$ are appropriate to treat diabetes mellitus.

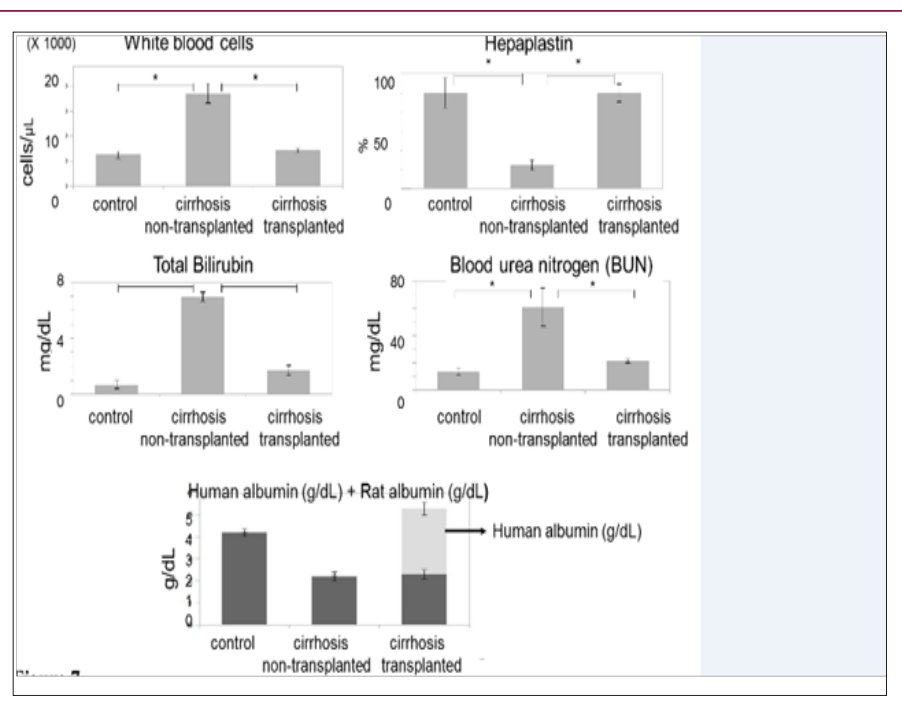

Figure 7: Treatment of liver cirrhosis in rats using regenerated hepatic cells originating from human tooth pulp. Cirrhosis nontransplanted demonstrated the typical results of blood examinations from cirrhotic rats, whereas cirrhosis transplanted, which had received transplantation of hepatocyte-like cells originating from human tooth cells, showed similar results to the control. More than half of the albumin was human albumin [85].
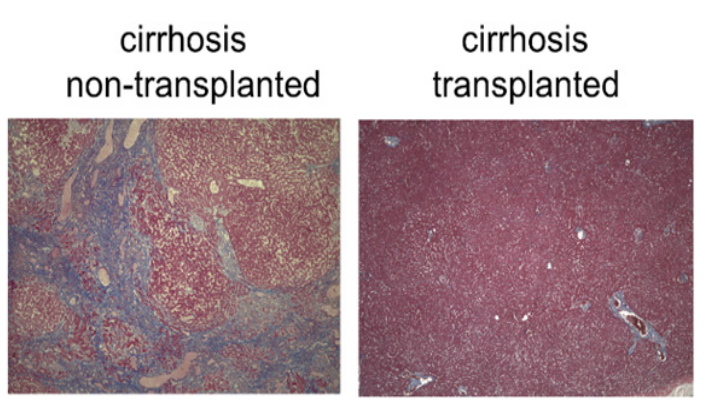

Figure 8: Treatment of liver cirrhosis in rats using regenerated hepatic cells originating from human tooth pulp. Cirrhosis non-transplanted demonstrated typical cirrhosis pathology, but fibrosis had disappeared in cirrhosis transplanted, which had received transplantation of hepatocyte-like cells originating from human tooth cells [85]. Masson's trichrome stain. Magnification 200×. 


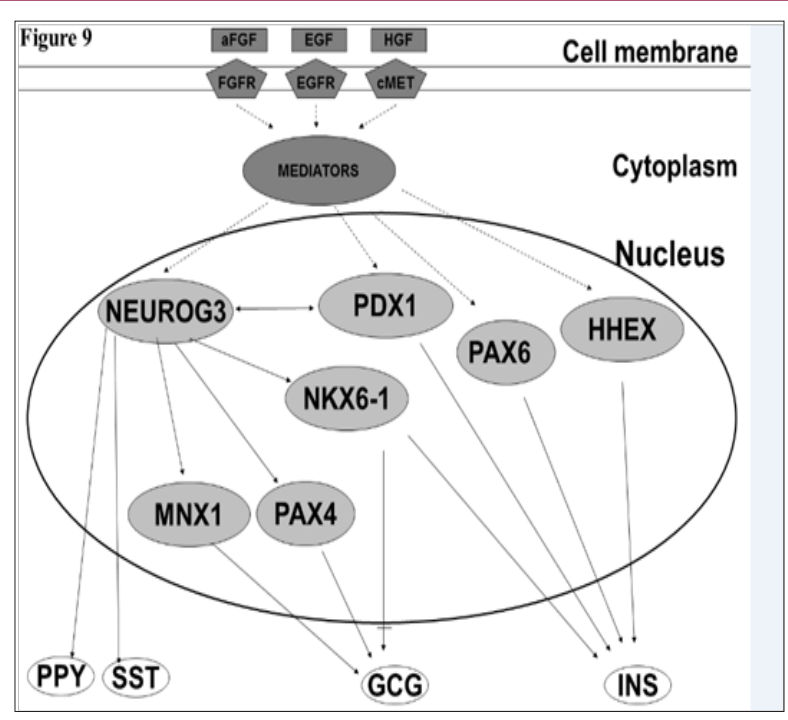

Figure 9: Pathways of pancreatic transcription factors and hormones. Analysis was performed by Ingenuity Pathway Analysis. FGF1, EGF and HGF utilized for the pancreatic differentiation protocol of human dental pulp activate the pancreatic transcription factors PDX1, HHEX, NEUROG3, PAX6, NKX6-1, Pax-4 and MNX1, and result in production of pancreatic hormones. Solid lines represent direct interactions. Dashed lines represent transduction pathways involving different and diverse cytoplasmic mediators activating the transcription factors in the nucleus. PPY: pancreatic polypeptide, SST: somatostatin, GCG: glucagon and INS: insulin [90].

To understand the relationship between $\mathrm{H}_{2} \mathrm{~S}$ and insulin or pancreas, the excellent review by Wang [91] is useful. He cited Patacchini et al. [92], Yang et al. [93] and Patel and Shah [94], and concluded that $\mathrm{H}_{2} \mathrm{~S}$ regulates insulin secretion from pancreatic $\beta$ cells by enhancing the KATP channel and suppressing L-type $\mathrm{Ca}^{2+}$ channel activities. KATP channels are activated by $\mathrm{H}_{2} \mathrm{~S}$ at concentrations, which is more than the $\mathrm{IC}_{50}$ of $\operatorname{COX}[9,92-94]$. Szabo et al. [95] wrote a review of the regulation of mitochondrial bioenergetic function by $\mathrm{H}_{2} \mathrm{~S}$. Interestingly, Okamoto et al. [96] described protective activities of $\mathrm{H}_{2} \mathrm{~S}$ on pancreatic $\beta$ cells. Insulin concentration in pancreatic cells or medium was determined when applying glucose stimulation (Figure 10) [43]. Exposure of the cells to $\mathrm{H}_{2} \mathrm{~S}$ increased intracellular or extracellular insulin concentration under no glucose stimulation. Glucose at $3.3 \mathrm{mM}$ increased insulin concentration in both the medium and the cells, and also in both the $\mathrm{H}_{2} \mathrm{~S}$-treated and non-treated groups. However, stimulation with $16.7 \mathrm{mM}$ glucose decreased insulin production compared with 3.3 $\mathrm{mM}$ glucose, except in the medium without $\mathrm{H}_{2} \mathrm{~S}$ exposure.

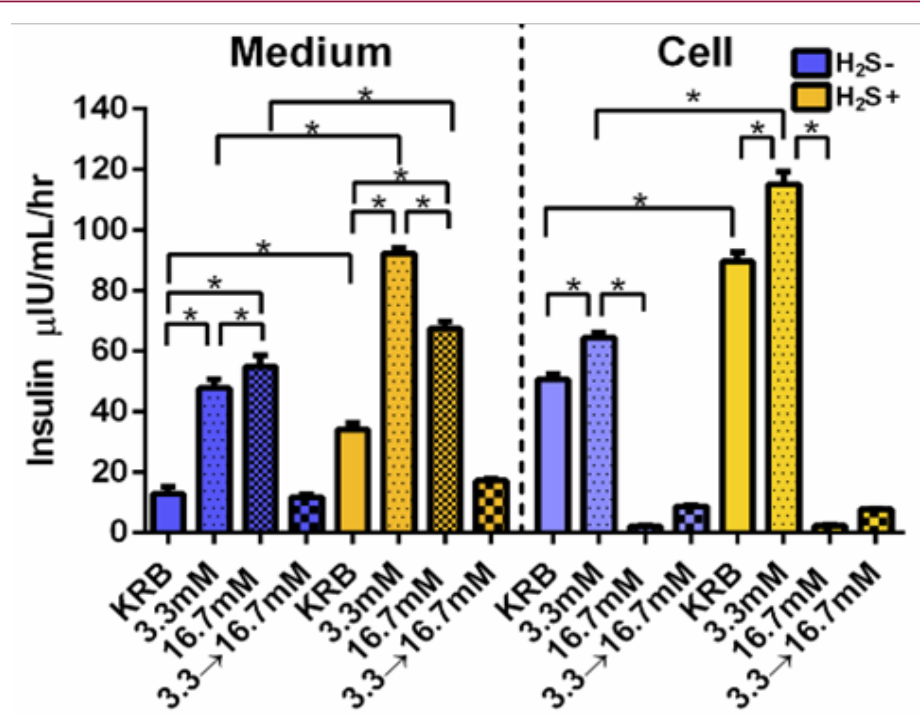

Figure 10: Glucose stimulation of pancreatic cells originating from human tooth pulp. Without glucose stimulation $\mathrm{H}_{2} \mathrm{~S}$ increased insulin concentration. Glucose at $3.3 \mathrm{mM}$ increased insulin concentration in both the medium and the cells, and also in both the $\mathrm{H}_{2} \mathrm{~S}+$ and $\mathrm{H}_{2} \mathrm{~S}$ - groups. However, $16.7 \mathrm{mM}$ glucose stimulation decreased insulin concentration compared with 3.3 mM glucose.

Moreover, $16.7 \mathrm{mM}$ glucose stimulation following $3.3 \mathrm{mM}$ glucose decreased insulin concentration greatly (Figure 10). However, the amount of C-peptide inside the cells showed the highest value in those treated with $16.7 \mathrm{mM}$ glucose stimulation following $3.3 \mathrm{mM}$ 
glucose under $\mathrm{H}_{2} \mathrm{~S}$ exposure. This means that when the first stimulation with $3.3 \mathrm{mM}$ was carried out, the cell was already exhausted [43]. On the other hand it was found their pancreas-like $\beta$ cell has same function for insulin secretion as shown in the cells derived from human embryonic stem cells [97]. WNT signaling is mainly composed of the canonical pathway, the planar-cell polarity pathway, and a calcium-ion-dependent pathway. All these pathways were activated by $\mathrm{H}_{2} \mathrm{~S}$, but expression of WNT-signaling negativeregulation genes was very weak [43] $\mathrm{H}_{2} \mathrm{~S}$ increased the level of expression in PI3K-AKT-related genes [43]. This pathway involves the following: AKT and PI3K family members and their regulators, the IGF-1 signaling pathway, the BAD phosphorylation and antiapoptotic pathways, the inactivation of Gsk3 and accumulation of $\beta$-Catenin, and PTEN-dependent cell-cycle arrest and apoptosis. Genes involved in all functions of the PI3K-AKT signaling pathway were significantly expressed after $\mathrm{H}_{2} \mathrm{~S}$ exposure compared with the non-treated group [43]. It was elucidated that $\mathrm{H}_{2} \mathrm{~S}$ promotes the differentiation from human-tooth pulp through WNT signaling and PI3K-AKT pathways. The data using both $1 \mathrm{nM}$ of $\mathrm{H}_{2} \mathrm{~S}$ and adult stem cells showed that lower concentration of $\mathrm{H}_{2} \mathrm{~S}$ strongly promotes differentiation of adult stem cells, a possibility of reversal ageing using $\mathrm{H}_{2} \mathrm{~S}$, i.g. $\mathrm{H}_{2} \mathrm{~S}$ releasing NSAIDs, is suggested.

\section{Conclusion}

$\mathrm{H}_{2} \mathrm{~S}$ promotes ROS production, DNA damage and p53mediated apoptosis at much lower concentrations than previously reported. The lowest concentration of $\mathrm{H}_{2} \mathrm{~S}$ promotes both hepatic and pancreatic differentiation of human-tooth pulp stem cells. The real concentration of $\mathrm{H}_{2} \mathrm{~S}$ is only around $\mathrm{nM}$ level in human tissues, less than one thousandth of the concentration previously claimed. Moreover less than one- thousandth or hundredth of the concentration previously reported showed the toxicities causing apoptosis in many tissues. Low concentration such as $1 \mathrm{nM}$ promotes hepatic and pancreatic differentiation from human tooth through WNT signaling and PI3K-AKT pathways.

\section{Acknowledgement}

The author thanks Drs. Ishikawa H, Nakahara T, Imai T, Kumazawa Y, Tanaka T and his previous and present PhD students for their excellent work.

\section{References}

1. Dorman DC, Moulin FJ, McManus BE, Mahle KC, James RA, et al. (2002) Cytochrome Oxidase inhibition induced by acute hydrogen sulfide inhalation: correlation with tissue sulfide concentrations in the rat brain, liver, lung, and nasal epithelium. Toxicol Sci 65(1): 18-25.

2. Khan AA, Schuler MM, Prior MG, Yong S, Coppock RW, et al. (1990) Effects of hydrogen sulfide exposure on lung mitochondrial respiratory chain enzymes in rats. Toxicol Appl Pharmacol 103(3): 482-490.

3. Nicholls P, Kim JK (1982) Sulphide as an inhibitor and electron donor for the cytochrome c oxidase system. Can J Biochem 60(6): 613-623.

4. Morii D, Miyagatani Y, Nakamae N, Murao M, Taniyama K (2010) Japanese experience of hydrogensulfide: the suicide craze in 2008. Journal of Occupational Medicine and Toxicology.

5. Völkel S, Griesharber MK (1997) Sulphide oxidation and oxidative phosphorylation in the mitochondria of the lugworm. J Exp Biol 200: 83-92.
6. Nicholson RA, Roth SH, Zhang A, Zheng J, Brookes J, et al. (1998) Inhibition of respiratory and bioenergetic mechanisms by hydrogen sulfide in mammalian brain. J Toxicol Environ Health 54(6): 491-507.

7. Liu Y, Luo H, Liang C, Mingkai chen (2013) Actions of hydrogen sulfide and ATP-sensitive potassium channels on colonic hypermotility in a rat model of chronic stress PLoS One 8(2): e55853.

8. Barr LA, Calvert JW (2014) Discoveries of hydrogen sulfide as a novel cardiovascular therapeutic. Circ J 78(9): 2111-2118.

9. Wang R (2003) The gasotransmitter role of hydrogen sulfide Antioxid. Redox Signal 5(4):93-501.

10. Riahi S, Rowley CN (2014) Why can hydrogen sulfide permeate cell membranes? J Am Chem Soc 136(43): 15111-15113.

11. Eghbal MA, Pennefather PS, O’Brien PJ (2004) $\mathrm{H}_{2} \mathrm{~S}$ cytotoxicity mechanism involves reactive oxygen species formation and mitochondrial depolarisation. Toxicology 203(1-3): 69-76.

12. Julian D, April KL, Patel S, Stein JR,Wohlgemuth SE (2005) Mitochondrial depolarization following hydrogen sulfide exposure in erythrocytes from a sulfide-tolerant marine invertebrate J Exp Biol 208(pt 21): 41094122.

13. Yang C, Zhanli Y, Meifen Z, Feng J (2011) Hydrogen sulfide protects against chemical hypoxia-induced cytotoxicity and inflammation in HaCaT cells through inhibition of ROS/NF-кB/COX-2 pathway. PLoS One 6(7): e21971.

14. Geng B, Chang L, Pan C, Qi Y, Zhao J, et al. (2004) Endogenous hydrogen sulfide regulation of myocardial injury induced by isoproterenolBiochem. Biophys Res Commun 318(3): 756-763.

15. Sun WH, Liu F, Chen Y, Zhu YC (2012) Hydrogen sulfide decreases the levels of ROS by inhibiting mitochondrial complex IV and increasing SOD activities in cardiomyocytes under ischemia/reperfusion Biochem. Biophys Res Commun 421(2): 164-169.

16. Dong XB, Meifen Z, Xin Xue L, Chen PX, et al. (2012) Inhibition of ROSactivated ERK1/2 pathway contributes to the protection of $\mathrm{H}_{2} \mathrm{~S}$ against chemical hypoxia-induced injury in H9c2 cells. Mol Cell Biochem 362(12): 149-157.

17. Wu D, Hu Q, Liu X, Pan L, Xiong Q et al. (2015) Hydrogen sulfide protects against apoptosis under oxidative stress through SIRT1 pathway in H9c2 cardiomyocytes. Nitric Oxide 46: 204-212.

18. Yin J, Tu C, Zhao J, Ou D, Chen G, et al. (2013) Exogenous hydrogen sulfide protects against global cerebral ischemia/reperfusion injury via its anti-oxidative, anti-inflammatory and anti-apoptotic effects in rats. Brain Res 1491: 188-196.

19. Xie H, Xu Q, Jia J, Ao G, Sun Y (2015) Hydrogen sulfide protects against myocardial ischemia and reperfusion injury by activating AMP-activated protein kinase to restore autophagic flux Biochem. Biophys Res Commun 458(3): 632-638.

20. Shibuya N, Kimura H (2013) Production of hydrogen sulfide from d-cysteine and its therapeutic potential. Front Endocrinol (Lausanne).

21. Wang X, Wang Q, Guo W, Zhu YZ (2011) Hydrogen sulfide attenuates cardiac dysfunction in a rat model of heart failure: a mechanism through cardiac mitochondrial protection. Biosci Rep 31(2): 87-98.

22. Haouzi P, Chenuel B, Sonobe T (2015) High-dose hydroxocobalamin administered after $\mathrm{H}_{2} \mathrm{~S}$ exposure counteracts sulfide-poisoning-induced cardiac depression in sheep Clin. Toxicol (Phila) 53(1): 5328-5336.

23. Fawcett EM, Hoyt JM, Johnson JK, Miller DL (2015) Hypoxia disrupts proteostasis in Caenorhabditis elegans Aging Cell 14(1): 92-101.

24. Zhou Y, Wang D, Gao X, Lew K, Richards AM, et al. (2014) mTORC2 phosphorylation of Akt1: a possible mechanism for hydrogen sulfideinduced cardioprotection. PLoS One 9(6): e99665.

25. Sun Y, Tang CS, DU JB, Jin HF (2011) Hydrogen sulfide and vascular relaxation Chin Med J (Engl) 124(22): 3816-3819. 
26. Cooper CE, Brown GC (2008) The inhibition of mitochondrial cytochrome oxidase by the gases carbon monoxide, nitric oxide, hydrogen cyanide and hydrogen sulfide: chemical mechanism and physiological significance. J Bioenerg Biomembr 40: 533-539.

27. Furne J, Saeed A, Levitt MD (2008) Whole tissue hydrogen sulfide concentrations are orders of magnitude lower than presently accepted values. Am J Physiol Regul Integr Comp Physiol 295(5): R1479-1485.

28. Ebbing D, Gammon SD (2010) Acid base reactions with gas formation ( $9^{\text {th }}$ Edn.). Ebbing D and Gammon SD Gengage Learning United States Indianapolis KY, General Chemistry, USA, p. 143.

29. Yaegaki K, Donald MB, Albert Tangerman, Yong-Sahm Choe, Edwin G Winkel, et al. (2012) Standardization of clinical protocols in oral malodor research J Breath Res 6(1).

30. DeLeon ER, Stoy GF, Olson KR (2012) Passive loss of hydrogen sulfide in biological experiments. Anal Biochem 421(1): 203-207.

31. Ariyaratnam P, Loubani M, Morice AH (2013) Hydrogen sulphide vasodilates human pulmonary arteries: a possible role in pulmonary hypertension? Microvasc Res 90: 135-137.

32. Shen X, Pattillo CB, Pardue S, Bir SC, Wang R, et al. (2011) Measurement of plasma hydrogen sulfide in vivo and in vitro. Free Radic Biol Med 50(9): 1021-1031.

33. Gilboa-Garber N (1971) Direct spectrophotometric determination of inorganic sulfide in biological materials and in other complex mixtures. Anal Biochem 43(1): 129-133.

34. Lee SK, Chung JH, Choi SC, Auh QS, Lee YM, et al. (2013) Sodium hydrogen sulfide inhibits nicotine and lipopolysaccharide-induced osteoclastic differentiation and reversed osteoblastic differentiation in human periodontal ligament cells. J Cell Biochem 114(5): 1183-1193.

35. Wang Z, Liu DX, Wang FW, Zhang Q, Du ZX, et al. (2013) L-Cysteine promotes the proliferation and differentiation of neural stem cells via the $\mathrm{CBS} / \mathrm{H}_{2} \mathrm{~S}$ pathway Neuroscience 237: 106-117.

36. Calenic B, Yaegaki K, Murata T, Imai T, Aoyama I, et al. (2010) Oral malodorous compound triggers mitochondrial-dependent apoptosis and causes genomic DNA damage in human gingival epithelial cells J Periodontal Res 45(1): 31-37.

37. Ii H, Imai T, Yaegaki K, Irie K, Ekuni D (2010) Oral malodorous compound induces osteoclast differentiation without receptor activator of nuclear factor $\kappa B$ ligand. J Periodontol 81: 1691-1697.

38. Kimura Y, Kimura H (2004) Hydrogen sulfide protects neurons from oxidative stress. FASEB J 18 (10):1165-1167.

39. Ostrakhovitch EA, Akakura S, Sanokawa-Akakura R, Goodwin S, Tabibzadeh S (2015) Dedifferentiation of cancer cells following recovery from a potentially lethal damage is mediated by $\mathrm{H}_{2} \mathrm{~S}$-Nampt. Exp Cell Res 330: 135-150.

40. Fukami K, Kawabata A (2015) Hydrogen sulfide and neuronal differentiation: Focus on $\mathrm{Ca}_{2}{ }^{+}$channels. Nitric Oxide 46: 50-54.

41. Ishkitiev N, Calenic B, Aoyama I, Ii H, Yaegaki K et al. (2012) Hydrogen sulfide increases hepatic differentiation in tooth-pulp stem cells. J Breath Res 6(1).

42. Okada M, Ishkitiev N, Yaegaki K, Imai T, Tanaka T, et al. (2014) Hydrogen sulfide increases hepatic differentiation of human tooth-pulp stem cells compared with human bone-marrow stem cells. Int Endod J 47(12): 1142-1150.

43. Okada M, Imai T, Yaegaki K, Ishkitiev N, Tanaka T (2014) Regeneration of insulin-producing pancreatic cells using a volatile bioactive compound and human teeth. J Breath Res 8 /4/046004.

44. Ago M, Ago K, Ogata M (2008) Two fatalities by hydrogen sulfide poisoning: variation of pathological and toxicological findings. Leg Med (Tokyo) 10: 148-152.

45. Wong PT, Kun Qu, Ghislain Chimon, Christopher LH Chen (2006) High plasma cyst(e)ine level may indicate poor clinical outcome in patients with acute stroke: possible involvement of hydrogen sulfide. J Neuropathol Exp Neurol 65(2):109-115.

46. Mann NS, Rossaro L (2006) Sudden infant death syndrome: the colon connection. Med Hypotheses 66(2): 375-379.

47. Truong DH, Eghbal MA, Hindmarsh W, Roth S, O’Brien PJ (2006) Molecular mechanisms of hydrogen sulfide toxicity. Drug Metab Rev 38(4): 733-744.

48. Wu S, Zhou F, Wei Y, Chen WR, Chen Q et al. (2014) Cancer phototherapy via selective photoinactivation of respiratory chain oxidase to trigger a fatal superoxide anion burst Antioxid. Redox Signal 20(5): 733-746.

49. Zhou Y, Wang D, Gao X, Lew K, Richards AM, et al. (2014) mTORC2 phosphorylation of Akt1: a possible mechanism for hydrogen sulfideinduced cardioprotection. PLoS One 9(6): e99665.

50. Turrens JF (2003) Mitochondrial formation of reactive oxygen species. J Physiol 552(Pt 2): 335-344.

51. Zhen Y, Pan W, Hu F, Wu H, Feng J, et al. (2015) Exogenous hydrogen sulfide exerts proliferation/anti-apoptosis/angiogenesis/migration effects via amplifying the activation of NF- $\kappa B$ pathway in PLC/PRF/5 hepatoma cells. Int J Oncol 46: 2194-2204.

52. Kovacic S, Soltys CL, Barr AJ, Shiojima I, Walsh K, et al. (2003) Akt activity negatively regulates phosphorylation of AMP-activated protein kinase in the heart. J Biol Chem 278: 39422-39427.

53. Persson S (1992) Hydrogen sulfide and methyl mercaptan in periodontal pockets. Oral Microbiol Immunol 7(6): 378-379.

54. Yaegaki K, Qian W, Murata T, Imai T, Sato T, et al. (2008) Oral Malodorous Compound Causes Apoptosis and Genomic DNA Damage in Human Gingival Fibroblasts. J Periodontal Res 43(4): 391-399.

55. Shibuya N, Koike S, Tanaka M, Ishigami-Yuasa M, Kimura Y, Ogasawara, et al. (2013) A novel pathway for the production of hydrogen sulfide from dcysteine in mammalian cells. Nat Commun 4: 1366.

56. Carter WO, Narayanan PK, Robinson JP (1994) Intracellular hydrogen peroxide and superoxide anion detection in endothelial cells. J Leukoc Biol 55(2): 253-258.

57. Calenic B, Yaegaki K, Kozhuharova A, Imai T (2010) Oral malodorous compound causes oxidative stress and p53-mediated programmed cell death in keratinocyte stem cells. J Periodontol 81(9): 1317-1323.

58. Calenic B, Ishkitiev N, Yaegaki K, Imai T, Kumazawa Y, et al. (2010) Magnetic separation and characterization of keratinocyte stem cells from human gingiva. J Periodontal Res 45(6): 703-708.

59. Kobayashi C, Ishkitiev DDS, ToshioImai, HisatakaIi DDS, IzumiAoyama DDS, et al. (2011) Hydrogen sulfide causes apoptosis in human pulp stem cells. J Endod 37(4): 479-484.

60. Fujimura M, Calenic B, Yaegaki K, Murata T, Ii H, et al. (2010) Oral malodorous compound activates mitochondrial pathway inducing apoptosis in human gingival fibroblasts. Clin Oral Investig 14(4): 367373 .

61. Calenic B, Yaegaki K, Ishkitiev N, Kumazawa Y, Imai T, et al. (2013) p53Pathway activity and apoptosis in hydrogen sulfide-exposed stem cells separated from human gingival epithelium J Periodontal Res 48(3): 322330.

62. Thompson RW, Valentine HL, Valentine WM (2003) Cytotoxic mechanisms of hydrosulfide anion and cyanide anion in primary rat hepatocyte cultures. Toxicology 188(2-3): 149-159.

63. Ng W, Tonzetich J (1984) Effect of hydrogen sulfide and methyl mercaptan on the permeability of oral mucosa. J Dent Res 63(7): 994-997.

64. Baskar R, Li L, Moore PK (2007) Hydrogen sulfide-induces DNA damage and changes in apoptotic gene expression in human lung fibroblast cells. FASEB J 21(1): 247-255.

65. Fairbairn DW, Olive PL, O'Neill KL (1995) The comet assay: a comprehensive review Mutat. Res 339(1): 37-59. 
66. Cohen GM (1997) Caspases: the executioners of apoptosis. Biochem J 326(1): 1-16

67. Aoyama I, Calenic B, Imai T, Ii H, Yaegaki K (2012) Oral malodorous compound causes caspase- 8 and -9 mediated programmed cell death in osteoblasts. J Periodontal Res 47: 365-373.

68. Yang G, Sun X, Wang R (2004) Hydrogen sulfide-induced apoptosis of human aorta smooth muscle cells via the activation of mitogen-activated protein kinases and caspase-3 FASEB J 18(14): 1782-1784.

69. Cheung NS, Peng ZF, Chen MJ, Moore PK, Whiteman M (2007) Hydrogen sulfide induced neuronal death occurs via glutamate receptor and is associated with calpain activation and lysosomal rupture in mouse primary cortical neurons. Neuropharmacology 53(4): 505-514.

70. Takeuchi H, Setoguchi T, Machigashira M, Kanbara K, Izumi Y (2008) Hydrogen sulfide inhibits cell proliferation and induces cell cycle arrest via an elevated p21 Cip1 level in Ca9-22 cells. J Periodontal Res 43(1): 90-95.

71. Chipuk JE, Kuwana T, Bouchier-Hayes L, Droin NM, Newmeyer DD, et al. (2004) Direct activation of Bax by p53 mediates mitochondrial membrane permeabilization and apoptosis. Science 303(5660): 10101014.

72. Imai T, Ii H, Yaegaki K, Murata T, Sato T, et al. (2009) Oral malodorous compound inhibits osteoblast proliferation. J Periodontol 80(12): 20282034 .

73. Kurabayashi M (2014) Hydrogen sulfide: a new regulator of osteoclastogenesis? Arterioscler Thromb Vasc Biol 34(3): 471-473.

74. Lee SK, Chung JH, Choi SC, Auh QS, Lee YM, et al. (2013) Sodium hydrogen sulfide inhibits nicotine and lipopolysaccharide-induced osteoclastic differentiation and reversed osteoblastic differentiation in human periodontal ligament cells. J Cell Biochem 114: 1183-1193.

75. Sekiguchi F, Miyamoto Y, Kanaoka D, Ide H, Yoshida S, et al. (2014) Endogenous and exogenous hydrogen sulfide facilitates T-type calcium channel currents in Cav3.2-expressing HEK293 cells. Biochem Biophys Res Commun 445(1): 225-229.

76. Okubo K, Matsumura M, Kawaishi Y, Aoki Y, Matsunami M, et al. (2012) Hydrogen sulfide-induced mechanical hyperalgesia and allodynia require activation of both Cav3.2 and TRPA1 channels in mice $\mathrm{Br}$ J Pharmacol 166(5): 1738-1743.

77. Sekiguchi F, Kawabata A (2013) T-type calcium channels: functional regulation and implication in pain signaling. J Pharmacol Sci 122(4): 244-250.

78. Gottmann K, Dietzel ID, Lux HD, Huck S, Rohrer H (1988) Development of inward currents in chick sensory and autonomic neuronal precursor cells in culture. J Neurosci 8(10): 3722-3732.

79. Tarui T, Fukami K, Nagasawa K, Yoshida S, Sekiguchi F et al. (2010) Involvement of Src kinase in T-type calcium channel-dependent neuronal differentiation of NG108-15 cells by hydrogen sulfide. J Neurochem 114: 512-519.

80. Coyle JT, Puttfarcken P (1993) Oxidative stress, glutamate, and neurodegenerativedisorders Science 262(5134): 689-695.

81. Liu D, Wang Z, Zhan J, Zhang Q, Wang J, et al. (2014) Hydrogen sulfide promotes proliferation and neuronal differentiation of neural stem cells and protects hypoxia-induced decrease in hippocampal neurogenesis Pharmacol Biochem Behav 116: 55-63.
82. Jiang JM, Zhou CF, Gao SL, Tian Y, Wang CY, et al. (2015) BDNF-TrkB Pathway Mediates Neuroprotection of Hydrogen Sulfide against Formaldehyde-Induced Toxicity to PC12 Cells. PLoS One 10: e0119478.

83. Ross SE, Greenberg ME, Stiles CD (2003) Basic helix-loop-helix factors in cortical development Neuron. 39(1):13-25.

84. Zhao Y, Wei H, Kong G, Shim W, Zhang G (2013) Hydrogen sulfide augments the proliferation and survival of human induced pluripotent stem cell-derived mesenchymal stromal cells through inhibition of BKCa Cytotherapy 15(11): 1395-1405.

85. Ishkitiev N, Yaegaki K, Imai T, Tanaka T, Fushimi N, et al. (2015) Novel management of acute or secondary biliary liver conditions using hepatically-differentiated human dental-pulp cells Tissue Eng. Part A 21(3-4): 586-593.

86. Oricchio E, Eirini P Papapetrou, Fabien Lafaille, Yosif M Ganat, Sonja Kriks, et al. (2014) A Cell Engineering Strategy to Enhance the Safety of Stem Cell Therapies Cell Rep 8(6): 1677-1685.

87. Yomiuri online, Institute of Physical and Chemical Research (Japan) send-off their second operation using human iPS cells.

88. Ishkitiev N, Yaegaki K, Calenic B, Nakahara T, Ishikawa H, et al. (2010) Deciduous and permanent dental pulp mesenchymal cells acquire hepatic morphologic and functional features in vitro. J Endod 36(3): 469-474.

89. Hirata TM, Ishkitiev N, Yaegaki K, Calenic B, Ishikawa H, et al. (2010) Expression of multiple stem cell markers in dental pulp cells cultured in serum-free media. J Endod 36(7): 1139-1144.

90. Ishkitiev N, Yaegaki K, Kozhuharova A, Tanaka T, Okada M, et al. (2013) Pancreatic differentiation of human dental pulp $\mathrm{CD} 117^{+}$stem cells. Regen Med 8(5): 597-612.

91. Wang R (2012) Physiological implications of hydrogen sulfide: a whiff exploration that blossomed Physiol Rev 92(2): 791-896.

92. Patacchini R, Santicioli P, Giuliani S, Maggi CA (2004) Hydrogen sulfide $\left(\mathrm{H}_{2} \mathrm{~S}\right)$ stimulates capsaicin-sensitive primary afferent neurons in the rat urinary bladder. Br J Pharmacol 142(1): 31-34.

93. Yang W, Yang G, Jia X, Wu L, Wang R (2005) Activation of KATP channels by $\mathrm{H}_{2} \mathrm{~S}$ in ratinsulin-secreting cells and the underlying mechanisms. J Physiol 569: 519-531.

94. Patel MA, Shah GB (2010) Possible role of hydrogen sulfide in insulin secretion and in囚development of insulin resistance. J Young Pharmacists 2(2): 148-151.

95. Szabo C, Ransy C, Módis K, Andriamihaja M, Murghes B, et al. (2014) Regulation of mitochondrial bioenergetic function by hydrogen sulfide. Part I. Biochemical and physiological mechanisms. Br J Pharmacol 171(8): 2099-2122.

96. Okamoto M, Ishizaki T, Kimura T (2015) Protective effect of hydrogen sulfide on pancreatic beta-cells. Nitric Oxide 46: 32-36.

97. Pezzolla D, López Beas J, Lachaud CC, Domínguez Rodríguez A, Smani T, et al. (2015) Resveratrol Ameliorates the Maturation Process of $\beta$-Cell-Like Cells Obtained from an Optimized Differentiation Protocol of Human Embryonic Stem Cells. PLoS One 10(3): e0119904. 


\section{(C) (i) This work is licensed under Creative}

Submission Link: https://biomedres.us/submit-manuscript.php

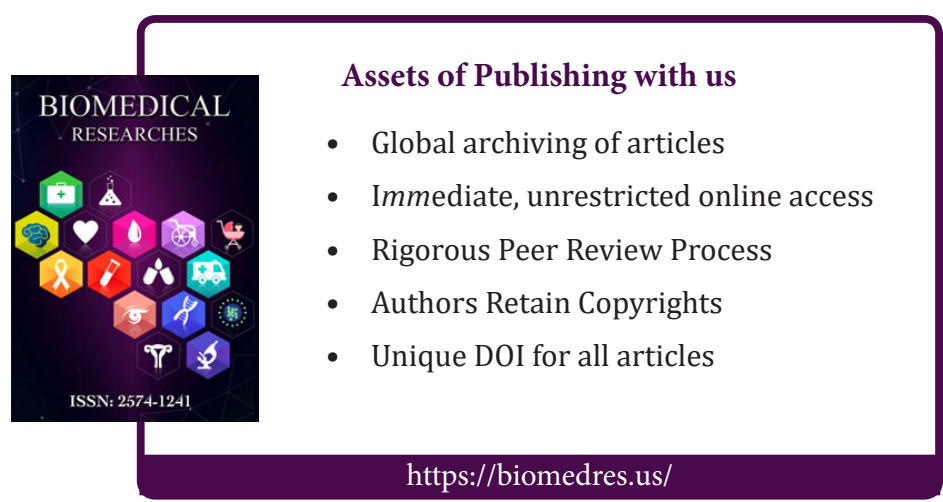

